\title{
PREVALENSI MALARIA PADA DAERAH ENDEMIS ORANG RIMBA PROVINSI JAMBI MENGGUNAKAN PEMERIKSAAN MIKROSKOPIS
}

\author{
Ade Suryaman*, Chairil Anwar, Dwi Handayani, Sulfa Esi Warni \\ Irsan Saleh, Dalillah, Gita Dwi Prasasty
}

\author{
Program Pasca Sarjana BKU Parasitologi, Program Studi Ilmu Biomedik \\ Fakultas Kedokteran Universitas Sriwijaya Sumatra Selatan. \\ Jl. Dr. Mohamad Ali, Palembang, Sumatra Selatan. \\ *Korespondensi penulis: adesuryaman@poltekkesjambi.ac.id
}

\begin{abstract}
ABSTRAK
Latar Belakang: Malaria masih menjadi masalah kesehatan dunia dengan angka tertinggi terjadi di wilayah tropis dan subtropis salah satunya di Indonesia. Orang Rimba merupakan suku terasing yang tinggal di pedalaman hutan Provinsi Jambi yang keberadaan banyak terkonsentrasi pada daerah Taman Nasional Bukit Duabelas dan sebelah utara di Taman Nasional Bukit Tigapuluh. Administrasi kependudukan mereka tidak teregistrasi, dengan budaya nomaden menjadikan dokumentasi status kesehatan menjadi sulit. Terbatasnya transportasi, tempat tianggal di dalam hutan, pendidikan rendah, lingkungan tinggal yang buruk, serta tingkat sosial dan tingkat ekonomi yang rendah akan mengakibatkan risiko tinggi angka kejadian malaria. Penelitian ini bertujuan untuk mengetahui prevalensi malaria pada daerah endemis Orang Rimba di Sungaiterap Desa Jelutih Kec. Batin XXIV Kab. Batang Hari Provinsi Jambi.

Metode: Penelitian ini berjenis deskriptif observasional dengan desain survei. Adapun sampel pada penelitian ini ialah seluruh Orang Rimba yang bersedia menjadi responden di Sungai Terap Desa Jelutih Kec. Batin XXIV Kab. Batang Hari Provinsi Jambi berjumlah 94 orang. Pemeriksaan malaria dilakukan dengan menggunakan metode mikroskopis Gold standar untuk mendeteksi keberadaan Plasmodium pada preparat apusan darah.

Hasil: Pemeriksaan preparat darah dengan menggunakan mikroskopis menunjukan 4,95\% malaria, dengan spesies vivax sebanyak 3,96\% dan spesies falciparum sebanyak 0,99\%.

Kesimpulan: Terdapat Prevalensi malaria yang tinggi pada Orang Rimba di Sungaiterap Desa Jelutih Kec. Batin XXIV
\end{abstract} Kab. Batang Hari Provinsi Jambi.

Kata Kunci: orang rimba; Suku Anak Dalam (SAD); prevalensi malaria; kejadian malaria; mikroskopis malaria

\section{THE PREVALENCE OF MALARIA ON ENDEMIC LOCATION OF ORANG RIMBA IN JAMBI PROVINCE USING MICROSCOPIC EXAMINATION}

\begin{abstract}
Background: Malaria remain a world health problem with the highest number of case are in tropic and subtropic country such as Indonesia. Orang Rimba is a native tribe living secluded deep in the Taman Nasional Bukit Duabelas Forest and in the northern area were living in the Taman Nasional Bukit Tigapuluh. For demography, tteh were unregistered due to the difficulties of the survey, since they were living nomaden. Lack of transportation, living deep in the forest, low education level, bad living environment and low social economic level affect the risk of Malaria case number. This research amied to identifiy the prevalence of Malaria on endemic location of orang rimba in jambi province using microscopic examination.

Methods: This was a descriptive observational study. The population in this study were all communities of Anak Rimba. A total of 94 Anak Rimba were recruited for the study.Malaria status were checked using gold standar which is Microscopical examination of the blood smear.

Results: The results showed that 4,95\% of the respondents were positive Malaria with plasmodium vivax (3,96\%) and 0,99\% special falciparum

Conclusion: There were high prevalence of Malaria on Anak Rimba at Sungaterap Desa Jelutih, Kec. Batin XXIV, Kabupaten Batangahri, Provinsi Jambi
\end{abstract}

Keyword: orang rimba; Suku Anak Dalam (SAD); prevalence of malaria; malaria case, microscopic malaria; 


\section{PENDAHULUAN}

Malaria masih merupakan penyakit infeksi parasit paling penting di dunia yang disebabkan oleh genus Plasmodium hingga saat ini ada 6 spesies yang dapat menginfeksi manusia yaitu $P$. vivax, P.falciparum, $P$. ovale wallickeri, $P$. ovale curtisi, P. malariae, P. knowlesi. ${ }^{1}$ Angka kejadian malaria paling tinggi adalah diwilayah tropis dan subtropis, ditemukan ada peningkatan jumlah kasus malaria sebanyak dua juta kejadian dari tahun 2016 hingga 2017 selain dari itu ada tiga hingga empat miliar orang yang rentan mengalami infeksi malaria. ${ }^{2-4}$ Merujuk dari laporan yang dikeluarkan oleh Kementerian Kesehatan Republik Indonesia secara keseluruhan setiap tahun terjadi penuruanan angka kejadian malaria di Indonesia tergambar dari jumlah Anual Parasit Insiden di tahun 20017 adalah 0,99 menjadi 0,68 di tahun 2018 perseribu penduduk, sedangkan jumlah penderita malaria yang dikonfirmasi positif 180.205 orang, untuk di Provinsi Jambi pada tahun 2017 adalah 0,049 perseribu pendukuk dan pada 2018 menjadi 0,03 perseribu penduduk. ${ }^{5}$ penuruanan jumlah kejadian malaria mengindikasikan program eliminasi berjalan dengan baik, namun beberapa daerah masih digolongkan endemis dengan kriteria daerah terpencil, kondisi lingkungan yang kurang baik, pelayanan terhadap kesehatan yang sulit didapat, prilaku hidup masyarakat yang tidak sehat menjadikan rentan peningkatan kejadian malaria pada golongan masyarakat yang tiggal di daerah endemis. ${ }^{6}$

Dengan masih banyaknya daerah yang di golongkan endemis malaria di Provinsi Jambi terutama di daerah terpencil menjadikan kelompok masyarakat Orang Rimba sangat rentan terhadap timbulnya angka kejadian malaria, Orang Rimba adalah kelompok masyarakat yang sengaja mengasingkan diri dari lingkungan masyarakat modern dengan memilih bertempat tinggal di dalam hutan Jambi dan banyak dari mereka terkonsetrasi pada wilayah Bukit Duabelas dan Bukit Tigapulun dari Taman Nasional, untuk aturan sosial mereka memilikinya secara tersendiri, tidak memiliki rumah tetap karena Orang Rimba hidup dengan cara nomaden sehingga tidak memiliki batas wilayah, dan secara administrasi kependudukan masyarakat Orang Rimba masih belum teregistrasi. ${ }^{7}$ Jumlah populasi Orang Rimba Provinsi Jambi pada tahun 2010 tercatat sebanyak 3.205 orang dengan penyebaran hampir di seluruh kabupaten di Provinsi Jambi kecuali pada daerah perkotaan dan daerah yang dekat dengan perkotaan seperti Kabupaten Tanjung Jabung timur, Kabupaten Kerinci, kabupaten Muaro Jambi, Kota Jambi, dan Kota
Sungai Penuh. ${ }^{8}$ Budaya hidup Orang Rimba yang nomaden, tidak adanya registrasi pada data kependudukan menjadikan tidak adanya data keshatan, tempat tinggal Orang Rimba yang digolongkan pada diwilayah endemis mengakibatkan resiko tinggi mengalami malaria. ${ }^{7,9}$

Metode pemeriksaan malaria pada saat ini sudah sangat banyak dan berkembang, namun pemeriksaan menggunakan metode mikroskopis hingga saat ini masih menjadi Gold Standar dalam melakukan diagnostik malaria, hal ini dikarenakan metode miskroskopis adalah metode yang paling murah dan sensitif dalam melakukan diagnostik malaria jika kriterianya dipenuhi daintaranya dilakukan oleh tenaga ahli yang bepengalaman dan terlatih, melakukan pewarnaan yang tepat pada preparat yang akan diperiksa, lama pemeriksaan yang diperlukan dalam setiap pemeriksaan preparat, dan pemeliharaan mikroskop yang benar. Pemeriksaan dengan metode ini dapat mendeteksi dan mengidentifikasi parasit malaria pada densitas 10 hingga 30 parasit Plasmodium per mikrolieter darah. ${ }^{10}$

\section{METODE}

Penelitian ini berjenis deskriptif obserfasional dengan desain survey, adapun populasi dari penelitian ini ialah kelompok Orang Rimba Sungaiterap Desa Jelutih Kec. Batin XXIV Kab. Batang Hari Prov. Jambi. Sedangkan sampel dari penelitian ini aialah Orang rimba yang belum mendapatkan pengobatan anti malaria dan yang bersedia menjadi responden dari penelitian ini.

Dari penelitian ini diperoleh 99 sampel yang akan dilakukan pemeriksaan dengan metode mikroskopis, pembuatan preparat darah tebal bertujuan untuk mendeteksi keberadaan parsit, sedangkan preparat darah tipis bertujuan untuk mengidentifikasi spesies parasit. pembuatan preparat di awali dengan pengambilan darah tepi dan membubuhkanya pada kaca objek untuk pembuatan preparat tebal dan tipis.

Pengambilan darah tepi dilakukan dengan terlebih dahulu mendesinfeksi ujung jari, penusukan pada ujung jari dilakukan menggunakan jarum lanset, selanjutnya darah yang keluar dari bekas penusukan di bubuhkan pada kaca objek pertama, pembuatan apusan preparat tipis dilakukan dengan cara meletakan salah satu sisi dari kaca objek kedua tepat diatas tetes darah dengan sudut kemiringan 45 derajat, tunggu permukaan darah menyebar ke seluruh sisi kaca objek kedua tersebut, selanjutnya kaca objek digeser dengan sedikit tekanan dan dilakuakn 
secara stabil higga tetes darah tersebut menyebar merata dan tipis pada permukaan kaca objek.

Pembuatan apusan darah tebal pada kaca objek yang telah dibubuhkan tetesan darah dilebarkan dengan menggunakan ujung kaca objek lainya selebar 1-2 cm, setelah kering apusan tipis difiksasi menggunakan methanol, setelah kering dilakukan pewarnaan menggunakan giemsa dengan psikositas 2,5\% selama 45 menit atau pada psikositas giemsa 7,5\% dilakukan hanya 15 menit, setelah itu dilakukan pembilasan dengan menggunakan aquades dan disimpan untuk dilakukan pemeriksaan dibawah mikroskop. ${ }^{11}$

\section{HASIL DAN PEMBAHASAN}

Mayoritas responden tidak melaporkan adanya keluhan demam dan sakit kepala khas malaria dengan jumlah 94 orang responden, adapun karakteristik respondenya adalah 50\% Pria dan 50\% wanita dengan usia rata-rata adalah 25,6 tahun untuk pria, 25 tahun untuk wanita. Sedangkan responden yang melaporkan adanya keluhan demam dan sakit kepala adalah sebanyak 5 orang responden dengan karakteristik respondenya adalah $40 \%$ laki-laki dan $60 \%$ perempuan dengan usia rata-rata adalah 4 tahun untuk laki-kali dan 3,6 tahun untuk perempuan, sehingga usia rata-rata keseluruhan responden yang melaporkan adanya keluhan demam dan sakit kepala adalah 3,8 tahun, dengan rata-rata keluhan dirasakan dalam jangka waktu 2,4 bulan yang lalu sebelum pengambilan sampel dilakukan.

Tabel 1. Data Karakteristik Spesies dan Responden

\begin{tabular}{lc}
\hline Karakteristik & Jumlah \\
\hline Spesies Plasmodium & 1 \\
falciparum & - \\
malariae & 4 \\
vivax & - \\
knowlesi & \\
Responden tanpa keluhan demam & 47 \\
$\quad$ Pria & 47 \\
$\quad$ Wanita & \\
Responden dengan keluhan & \\
demam & 2 \\
$\quad$ Pria & 3 \\
$\quad$ Wanita & \\
(rata-rata usia penderita $=\mathbf{3 , 8}$ tahun)
\end{tabular}

Hasil dari pemeriksaan mikroskopis dari responden yang mengeluhkan adanya deman dan sakit kepala menunjukan keberadaan parasit dengan spesies vivax dan palcifarum dengan persentase vivax adalah 3,96\% dan falciparum adalah $0,99 \%$, parasit tersebut ditemukan berbentuk trofozoit, sehingga prevalensi malarianya adalah $4,95 \%$.

Alat diagnostik malaria yang dijadikan gold standart sampai dengan sekarang adalah masih menggunakan metode mikroskopis dengan kemapuan dalam melakukan deteksi yang cukup tinggi jika dikerjakan oleh tenaga laboran yang berpengalaman dan terlatih, waktu dalam melakukan pemeriksaan juga merupakan hal penting dalam keberhasilan melakukan deteksi dan identifikasi parasit pada preparat, sehingga pada kejadian luar biasa (KLB) akan mempengaruhi kemampuan dari metode pemeriksaan ini dikarenakan seorang tenaga laboran dituntut melakukan pemeriksaan dengan waktu cepat dan dengan jumlah preparat sampel yang banyak, dengan demikian semakin banyak waktu yang digunakan oleh tenaga laboran dalam memeriksa sebuah preparat akan meningkatkan kemampuan metode ini dalam mendeteksi dan mengidntifikasi keberadaan parasit hingga 10 sampai 30 parasit dalam satu mikroliter darah, namun pada densitas parasit yang lebih kecil metode ini sudah tidak lagi dapat mendeteksi keberadaan dari parasit. ${ }^{10,11}$

Pada penelitian yang dilakukan di Serawak Malaysia tahun 2004 ditemukan adanya spesies $P$. knowlesi yang diketahui sebelumnya menyerang primata kera ekor panjang dan kera ekor babi di dapati menginfeksi manusia yang dalam pemeriksaan menggunakan metode mikroskopis akan sangat besar kemungkinan terjadi salah pembacaan slide preparat hal ini dikarenakan pada gambaran morfologi trofozoit fase awal dari spesies $P$. knowlesi ini mirip dengan gambaran morfologi trofozit spesies $P$. falcifarum, sedangkan pada gambaran morfologi trofozoit lanjut spesies ini mirim dengan gambaran morfologi dari spesies $P$. malariae, di dalam hutan tempat tianggal Orang Rimba banyak terdapat kera ekor panjang sehingga jika hanya menggunakan pemeriksaan mikroskopis saja kemungkinan akan terjadi kesalahan dalam mengindetifikasi spesies parasit, maka dari itu diperlukan pemeriksaan pembanding dengan metode diagnostik lainya. ${ }^{12}$

Letak georafi indonesia yang berada di katulistiwa menjadikanya indonesia beriklim tropis ditambah lagi lingkungan tinggal Orang Rimba yang berada didalam hutan akan mengakibatkan meningkatnya angka kejadian malaria karena dapat digolongkan sebagai daerah endemis. ${ }^{6,9}$ Dari data hasil diperlihatkan usia ratarata yang mengeluhkan adanya demam dan sakit kepala serta dari hasil pemeriksaan yang telah dilakukan memperlihatkan adanya postif malaria yaitu pada usia rata-rata 3,8 tahun, hal ini dapat 
saja dikarenakan pada kelompok usia kurang dari 5 tahun merupakan kelopok rentan terhadap terjangkitnya malaria yang disebabkan oleh kemapuan sitem imun yang masih rendah. ${ }^{9}$

Gejala akut malaria seperti demam dan sakit kepala dapat timbul pada keadaan dimana kepadatan parasit dalam darah lebih tinggi sehingga mengakibatkan sistem imun tidak dapat mengendalikan parasit yang akan menyebabkan munculnya gejala, namun terkadang malaria sering timbul dengan tanpa adanya gejala akut atau malaria asimptomatik sehingga tidak menunjukan adanya demam dan sakit kepala terutama pada individu yang berada di daerah endmis dan individu tersebut belum mendapatkan pengobatan anti malaria dalam jangka waktu yang dekat, hal semacam ini dimungkinkan oleh kemampuan sistem imun dari hospes perantara yang komppeten sehingga dapat mengendalikan keadaan parasitemia namun tidak menyababkan hospes perantara menjadi sembuh dari keadaan parasitemia itu sendiri, selain itu keadaan seperti ini juga di mungkinkan karena kepadatan dari parasit yang berada didalam darah rendah, sehingga tidak tercapainya ambang batas pirogenik yang dapat mengakibatkan adanya gejala akut, keadaan semacam ini dapat dikategorikan sebagai malaria kronis, dengan demikian pemeriksaan manggunakan metode mikroskopis masih dipandang belum mampu mendeteksi keberadaan parasit pada darah sehingga perlu metode diagnostik lainya yang lebih sensitif sperti PCR. ${ }^{13,14}$

Dengan lingkungan tempat tinggal orang rimba di dalam hutan, dan permukaan tanah yang rendah memungkinkan banyaknya genagan air dan rawa yang dapat dimanfaatkan oleh nyamuk Anopheles sp sebagai vektor penyakit malaria untuk tempat perindukanya, kelembaban udara dan suhu daerah tropis dimana tempat tinggal Orang Rimba juga menjadikan ideal untuk perkembang biakan nyamuk Anopheles sp sehingga akan mengakibatkan populasi dari vektor malaria ini menjadi meingkat, dengan adanya nyamuk dan manusia siklus hidup dari parasit malaria dapat terpenuhi secara sempurna, sehingga akan menyebabkan penigkatan kejadian malaria pada Orang Rimba ${ }^{11,15}$

\section{KESIMPULAN}

Terdapat tinggi prevalensi malaria pada Orang Rimba, dengan lingkungan Orang Rimba memungkinkan terjadinya peningkatan angka kejadian malaria, selain itu juga perlu dilakukan pemeriksaan malaria dengan metode diagnostik yang lebih sensitif dan spesifik untuk mengetahui adanya malaria asimptomatik, Perlu melakukan pemeriksaan dengan metode diagnostik lain sebagai pembanding dalam mengindetifikasi spesies dengan lebih spesifik.

\section{DAFTAR PUSTAKA}

1. Milner DA. Malaria pathogenesis. Cold Spring Harb Perspect Med. 2018;8(1):1-11

2. WHO. World Malaria Report. Vol. 101, Revista medica de Chile. 2016. 252-256 p.

3. WHO. World Malaria Report 2017. World Health Organization. 2017. 1-238 p.

4. World Health Organization. WHO | The World malaria report 2018. Who. 2018. 22 p.

5. Kemenkes RI. Data dan informasi profile kesehatan Indonesia. 2018;

6. Dinas Kesehatan Provinsi Jambi. Profil Kesehatan Provinsi Jambi 2017. 2017;

7. Berdikarjaya, SE M, editor. Profil Suku Anak Dalam (SAD). BADANPUSATSTATISTIK PROVINSI JAMBI; 2010.

8. Jambi DKP. Profil Kesehatan Provinsi Jambi Tahun 2015. Dinas Kesehatan Provinsi Jambi 2014. 2015.

9. Abossie A, Yohanes T, Nedu A, Tafesse W, Damitie M. Prevalence of malaria and associated risk factors among febrile children under five years: A cross-sectional study in arba minch zuria district, south Ethiopia. Infect Drug Resist. 2020;13:36372.

10. Nkrumah B, Agyekum A, Acquah SEK, May J, Tannich E, Brattig N, et al. Comparison of the novel Partec rapid malaria test to the conventional Giemsa stain and the gold standard real-time PCR. J Clin Microbiol. 2010;48(8):2925-8.

11. Kemenkes RI. Pedoman Teknis Pemeriksaan Malaria. 2017;1-58.

12. Singh B, Daneshvar C. Human infections and detection of plasmodium knowlesi. Clin Microbiol Rev. 2013;26(2):165-84.

13. Doolan DL, Dobaño C, Baird JK. Acquired immunity to Malaria. Clin Microbiol Rev. 2009;22(1):13-36.

14. Okell LC, Bousema T, Griffin JT, Ouédraogo AL, Ghani AC, Drakeley CJ. Factors determining the occurrence of submicroscopic malaria infections and their relevance for control. Nat Commun. 2012;3:1-9.

15. Ponçon N, Toty C, L'Ambert G, Le Goff G, Brengues C, Schaffner F, et al. Biology and dynamics of potential malaria vectors in Southern France. Malar J. 2007;6. 